\title{
News Media Writing ${ }^{1}$
}

\author{
Ricky Telg and Lisa Lundy²
}

This publication covering an introduction to news media writing is the first of a five-part series on news media writing. This series also covers news writing for print, grammar and punctuation, news writing for television and radio, and interviews for news stories.

\section{Introduction}

Knowing how to write in a news media style is important not only for an organization's reporters, but also for its members. Because the news media-radio and television stations, newspapers, magazines, and digital news outlets-are where most people go for information, news stories have a significant impact on readers, viewers, and listeners. Knowing how to write a news story well and sending it to the news media, in the form of a news release, could mean that your information gets into a newspaper or on a radio or television newscast. Well-written articles also could be placed in your organization's newsletter or a trade publication.

News writing - also called journalistic writing—is similar to, yet slightly different than, "traditional" writing that you have done for most of your life. This publication provides an overview of news writing for text-based, television, and radio sources to help you better communicate news about what is going on in your organization.

\section{What Is News?}

One of the first things you have to determine before writing a news story is if the story is newsworthy. Television station news directors and newspaper editors use the following criteria to determine newsworthiness-what stories they will cover in their newscasts and newspapers:

- Timeliness refers to when an event or activity happened or when it will happen and implies immediacy or nearness to the present. Stories that reflect what is currently happening tend to be more newsworthy.

- Proximity or location refers to how close physically or psychologically the news story's content is to the audience. The closer the impact is geographically to the audience, the more proximity impact it has. For example, a news story for your organization's newsletter about a local member will have more proximity impact than a story about a member in another state. Sometimes, you can take a national story and add proximity for your local area. For example, how will state legislation on best management practices impact producers in your county?

- Prominence refers to the importance of the person or the event. Big names make big news. High-profile people, issues, or concerns have more news value.

- Importance or significance: The greater the effect and the larger the number of people impacted by your news story, the more likely it is that your story is news.

1. This document is AEC528, one of a series of the Department of Agricultural Education and Communication, UF/IFAS Extension. Original publication date January 2015. Revised June 2021. Visit the EDIS website at https://edis.ifas.ufl.edu for the currently supported version of this publication.

2. Ricky Telg, professor, and Lisa Lundy, professor, Department of Agricultural Education and Communication, UF/IFAS Extension, Gainesville, FL 32611.

The Institute of Food and Agricultural Sciences (IFAS) is an Equal Opportunity Institution authorized to provide research, educational information and other services

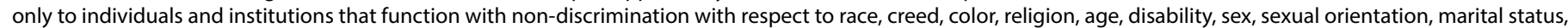

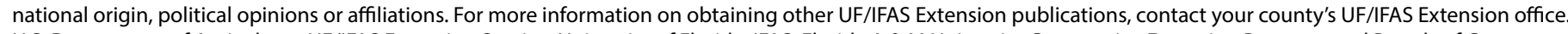
U.S. Department of Agriculture, UF/IFAS Extension Service, University of Florida, IFAS, Florida A \& M University Cooperative Extension Program, and Boards of County Commissioners Cooperating. Nick T. Place, dean for UF/IFAS Extension. 
- Human interest: News stories that have a strong appeal to human emotions are more newsworthy. Does the event involve interesting people doing interesting things? This is where storytelling can increase news value.

- Innovative or unusual: If the news story features something different, unusual, or innovative, it carries news value.

- Conflict: A story that shows struggles-for example, a person versus the environment, a person versus another person-is usually newsworthy.

- Money: News stories about financial issues are almost always newsworthy.

\section{News Writing Style}

To begin this section, it may be good to say what news writing style is not. It is not providing a chronological account of something that happened ("this happened, then this happened, then this happened"). News writing is not stringing together a long collection of direct quotations, one after the other. News writing is not starting out with the least important information first and then "springing" the news at the very end of the story.

News writing, very simply, is finding out:

Who said it, or who is it about?

\section{What happened?}

When did it happen?

Where did it happen?

Why is it important?

How did it happen?

Regardless of whether you write print, television, or radio stories, any journalistic writing should be accurate, brief, and clear.

Facts must be accurate; names must be spelled correctly, identifications made properly, and numeric figures quoted carefully. Never assume you have someone's name spelled correctly. Always ask the person how to spell his or her name. For example, a person by the name of "Jodi" could spell it "Jody" or "Jodie," and that name could be for a man or a woman. In addition, you add strength to accuracy by getting information from more than one source if possible. Two-source stories are always stronger and usually more accurate because you are not relying on just one person's thoughts. Accuracy is the reporter's greatest obligation to the reader. Being accurate also helps you maintain your credibility as a journalistic writer.

Journalistic writing also should be brief. Cut out unnecessary words. Find short words or phrases that mean the same thing as longer words or phrases. For example, use "whisper" instead of "talk softly." Overall, sentences should be 25 words or less. Paragraphs should be kept to three or fewer sentences. News stories also should get to the point quickly. What is the story about? What does the story need to tell the reader? A writer needs to be able to answer these questions in the simplest terms possible.

Finally, if the reader is to understand what is in the news article, the information must be clear. Write simply so you can communicate ideas without confusion. The reader should easily understand any information in an article. For example, eliminate all kinds of jargon, or technical language, spell out acronyms and avoid using big words to try to impress readers.

\section{Additional Information}

The Associated Press. (2022). The Associated Press stylebook and briefing on media law (55th ed.). New York: The Associated Press.

Burnett, C., \& Tucker, T. (2001). Writing for agriculture: A new approach using tested ideas (2nd ed.). Dubuque, IA.: Kendall/Hunt.

Oliu, W. E., Brusaw, C. T., \& Alred, G. J. (2007). Writing that works: Communicating effectively on the job (9th ed.). Boston: Bedford/St. Martin's.

Telg, R. \& Irani, T.A. (2012). Agricultural communications in action: A hands-on approach. Clifton Park, NY: Delmar. 